\title{
Wind characteristics of CzeCOS's ecosystem station Štítná
}

\author{
*Carlos P. Guerra Torres ${ }^{1,2,3}$, Vinh Xuan Nguyen ${ }^{1,2,4}$, Marian Pavelka ${ }^{1,5}$, \\ Shilpi Yadav ${ }^{1} \&$ Marek V. Michal $^{1}$
}

${ }^{1)}$ Global Change Research Institute, Bëlidla 986/4 A, StaréBrno, Czech Republic, e-mail: marek.mv@czechglobe.cz

${ }^{2}{ }^{2}$ Institute of Forest Ecology, Faculty of Forestry and Wood Technology, Mendel University in Brno, Zemédèlská 3, 61300 Brno, Czech Republic, e-mail:guerra.c@czechglobe.cz

${ }^{31}$ Department of Botany, University of Panama P. O.0824-00077 Panama, Panama, e-mail: guerra.c@czechglobe.cz

${ }^{4}$ Department of Ecology, Institute of Tropical Biology VAST, 85 Tran Quoc Toan Street, District 3, Ho Chi Minh

City,Vietnam,e-mail:nguyen.v@czechglobe.cz

${ }^{5)}$ Department of Silviculture, Faculty of Forestry and Wood Technology, Mendel University in Brno, Zemédèlská 3, 61300 Brno Czech Republic,e-mail:pavelka.m@czechglobe.cz

\begin{abstract}
Guerra Torres C. P., Nguyen V. X., Pavelka M., Yadav S., Marek M.V. 2017: Wind characteristics of CzeCOS's ecosystem station Štítná. - Beskydy, 10 (1, 2): 27-32

Accurate wind analyses using six wind classes and twelve splitting directions were done to deeply evaluate wind conditions on Štítná CzeCOS's ecosystem station in the Czech Republic. The analysis brings information about contribution of different part of the research-forested area to the measurement of $\mathrm{CO}_{2}$ exchange between the studied ecosystem and atmosphere. Štítná station is located inside of a forest composed of Fagus sylvatica with age 114 years and the forest can be harvested sometime forward. Total of $82 \%$ of the wind contributions speed are in the range of $1.0-6.0 \mathrm{~m} \mathrm{~s}^{-1}$ and the major accumulation of winds comes from SE (9\%), SSE (17\%) and S (14\%); $13 \%$ were calm periods. The obtained information will be useful for evaluate the conditions of the use of the eddy covariance technique in the research area.
\end{abstract}

Keywords: European beech, Fagus sylvatica, wind analysis.

\section{Introduction}

The basic method used for the measurement of the fluxes of carbon dioxide, water vapor, and energy between terrestrial ecosystems and the atmosphere in a specific area at a given hour, day, month or year is the eddy covariance method (EC). Eddy covariance is based on the analyses of the turbulent transport, and requires state-ofthe-art instruments, (Burba 2013; Aubinet et al. 2012; Baldocchi 2003).

A very important remark of the method is to assure that the measured of correct data are coming from the area of interest in order to address the fluxes of matter and energy balance to the station (Aubinet et al. 2012). The analysis of the wind speed and direction recreate where is the footprint of our area of interest. In this paper, we used the meteorological data required to develop the wind rose of the ecosystem station in Štítná. Is the main intention of this paper describe the wind contributions, directions and intensities of wind on Štítná EC research site in the Czech Republic. The main tree-specie in the site is the European beech and already reached the time of harvest; update the footprint of the site can provide useful recommendations to maintain the forest research (Savage and McInnes 1996). 


\section{Materials and Methods}

\section{Study area: Research station Štítná}

The ecosystem station of Štítná (STI) is located in the region of the White Carpathian Mountains in the East part of the Czech Republic $\left(49^{\circ} 02^{\prime} \mathrm{N}\right.$, $17^{\circ} 58^{\prime} \mathrm{E}, 550 \mathrm{~m}$ a.s.l.), on a slope $10^{\circ}$ with WSW orientation. STI is part of the Czech Carbon Observation System (CzeCOS) that serve for long-term observation of greenhouse gases and energy fluxes between ecosystem and the atmosphere in the Czech Republic. The composition of the vegetation cover is formed by a 114 years old (in 2017) forest stand of European beech (Fagus sylvatica). Alpine wrinkled tertiary rocks (slate, sandstone) form geological subsoil, cambisol is the soil in the region. From the point of view, the region is moderately warm, having averaged yearly temperature of $8.5^{\circ} \mathrm{C}$. The yearly precipitation ranges from $651-926 \mathrm{~mm}$ in STI during the years of this study. From the forestry point of view, the research station forest belongs to the fourth growing degree. In general terms, Štítná forest corresponds to the classification of Carpathian sub mountainous beech forest according to the European forest types (EEA 2007, Markova et al. 2017).

\section{Data acquisition and analysis}

The analyzed data belonged to the years 20122016 (CzechGlobe 2017). The data measured once every 10 minutes correspond to the wind speed, and wind direction at $44 \mathrm{~m}$ of height above the ground. The assigned quality of the data was summarized, to quantify it. The instrument used for obtain the wind values was a 50.5 Solid State Wind Sonic Sensor (Met One Instruments, U.S.A.). During this analysis, we considered some periods of wind related to the growing period of the beech stand forest and include the dates among March 15 - October 31 in every year.

The software used to analyze and create the wind rose graphs from the ecosystem station was the freeware WRPLOT View version 8.0.0 (www. weblakes.com). Once created the input required file for every year, the respective seasonal and yearly periods were created. The wind classes were stablished with the following six ranges: $1.0-2.0,2.0-4.0,4.0-6.0,6.0-8.0,8.0-10 \mathrm{~m} \mathrm{~s}^{-1}$ and bigger than $10 \mathrm{~m} \mathrm{~s}^{-1}$. Wind speed below $1.0 \mathrm{~m} \mathrm{~s}^{-1}$ were summarized and considered as calm periods in this study. The resulted images were plotted choosing twelve wind directions outline.

\section{Results}

The main wind speed characteristics and average in the tables 1 and 2 show that between $11 \%$ up to $16 \%$ of the wind measured every year in the ecosystem station were calm periods (slower than $1.0 \mathrm{~m} \mathrm{~s}^{-1}$ ) considered as calm periods mostly during nighttime. Is also visible that average wind speed was higher during daytime and calm periods were shorter. During the night time it was the opposite situation, i.e. wind speed lower and calm periods longer, reaching a little bit more than $26 \%$ of the total wind in the year 2016 (Tab. 1).

When we compared the period of 5 years of average wind speed (Tab. 1 against Tab. 2), it show increased in the Tab. 2 the value (Tab. 1 consider only growing period versus Tab. 2 which consider whole year measurements), but also the calm periods were longer in every year, but also in the five years together totalized. In the Tab. 2 we included the quality of the measurements of STI during the years considered. Most of the data from those years is very reliable from $97.3 \%-100 \%$ ranges as good quality (Tab. 2).

The wind rose in the figure 1 is resulted from the combination of all the periods from March 15 - October 31 during the years 2012 to 2016. The main wind speed contribution was that in the wind-class $2.0-4.0 \mathrm{~m} \mathrm{~s}^{-1}$ reaching $17.1 \%$ and mainly from the direction South South-East. The major source of winds comes from SE (9\%), SSE (17\%) and S (14\%) summarizing $40 \%$ of the total wind measured in the EC STI site. The maximum recorded wind speed by far in our station were registered on 17. 12. 2015 (during daytime winter period) reaching $14.8 \mathrm{~m} \mathrm{~s}^{-1}$.

In total $13.1 \%$ are calm periods and not contributing to create the wind of rose. We found that $82.3 \%$ of the wind contributions speed are in the range of 1.0-6.0 $\mathrm{m} \mathrm{s}^{-1}$. Almost none North wind contributions are part of the resultant wind rose. Since the utilized sonic anemometer had 360 wind direction range (Metone 2017), the nearly absence of North wind (1.06\%) must be influenced by the terrain orography/complexity and the tower position against the mountain edge, because the sonic anemometer showed no other North interference. 
Tab. 1: Summarized data of wind quality analysis in Štítná*, years 2012-2016.

\begin{tabular}{c|c|c|c|c|c|c}
\hline Years & $\begin{array}{c}\text { Year* } \\
\text { average wind } \\
\text { speed } \\
\left(\mathbf{m ~ s}^{-1}\right)\end{array}$ & $\begin{array}{c}\text { Year calm } \\
\text { periods } \\
(\%)\end{array}$ & $\begin{array}{c}\text { Daytime } \\
\text { average wind } \\
\text { speed } \\
\left(\mathbf{m ~ s}^{-1}\right)\end{array}$ & $\begin{array}{c}\text { Daytime } \\
\text { calm periods } \\
(\%)\end{array}$ & $\begin{array}{c}\text { Nighttime } \\
\text { average wind } \\
\text { speed } \\
\left(\mathbf{m} \mathbf{~ s}^{-1}\right)\end{array}$ & $\begin{array}{c}\text { Nighttime } \\
\text { calm periods } \\
(\%)\end{array}$ \\
\hline 2012 & 2.82 & 11 & 3.11 & 4 & 2.6 & 18 \\
2013 & 2.61 & 12 & 2.93 & 5 & 2.35 & 19 \\
2014 & 2.49 & 15 & 2.86 & 5 & 2.16 & 25 \\
2015 & 2.42 & 15 & 2.76 & 7 & 2.11 & 24 \\
2016 & 2.2 & 16 & 2.58 & 7 & 1.84 & 26 \\
$2012-16$ & 2.51 & 13 & 2.85 & 6 & 2.21 & 22 \\
\hline
\end{tabular}

* Considered from March 15 - October 31 (growing period).

Tab. 2: Summarized data from Wind analysis in Štítná using whole year data 2012-2016.

\begin{tabular}{c|c|c|c|c|c}
\hline \multirow{2}{*}{ Years } & \multirow{2}{*}{$\begin{array}{c}\text { Whole year average } \\
\text { wind speed }\left(\mathbf{m ~ s}^{-1}\right)\end{array}$} & \multirow{2}{*}{$\begin{array}{c}\text { Calm periods } \\
\text { (\%) }\end{array}$} & \multicolumn{3}{|c}{ Quality of measurements } \\
\cline { 4 - 6 } & & $1 \%)$ & \multicolumn{1}{|c}{$\mathbf{3}$} \\
\hline $2012^{*}$ & 2.86 & 12.23 & 99.5 & $0.4^{* *}$ & 0.1 \\
2013 & 2.59 & 14.92 & 98.2 & $1.8^{* * *}$ & 0 \\
2014 & 2.67 & 14.75 & 100 & 0 & 0 \\
2015 & 2.54 & 16.12 & 99.4 & $0.4 * *$ & $0.2^{* * *}$ \\
$2016^{*}$ & 2.34 & 16.29 & 97.3 & $2.7^{* * *}$ & 0 \\
$2012-2016$ & 2.60 & 14.86 & 98.8 & 1.1 & 0.1 \\
\hline
\end{tabular}

* Leap years;

Quality of measures 0 = measure with good quality; 2 = substituted value supplied by related sensor;

3 = substituted value of lowest quality; ${ }^{* *}$ not during growing period; $* * *$ only a part in the growing period.

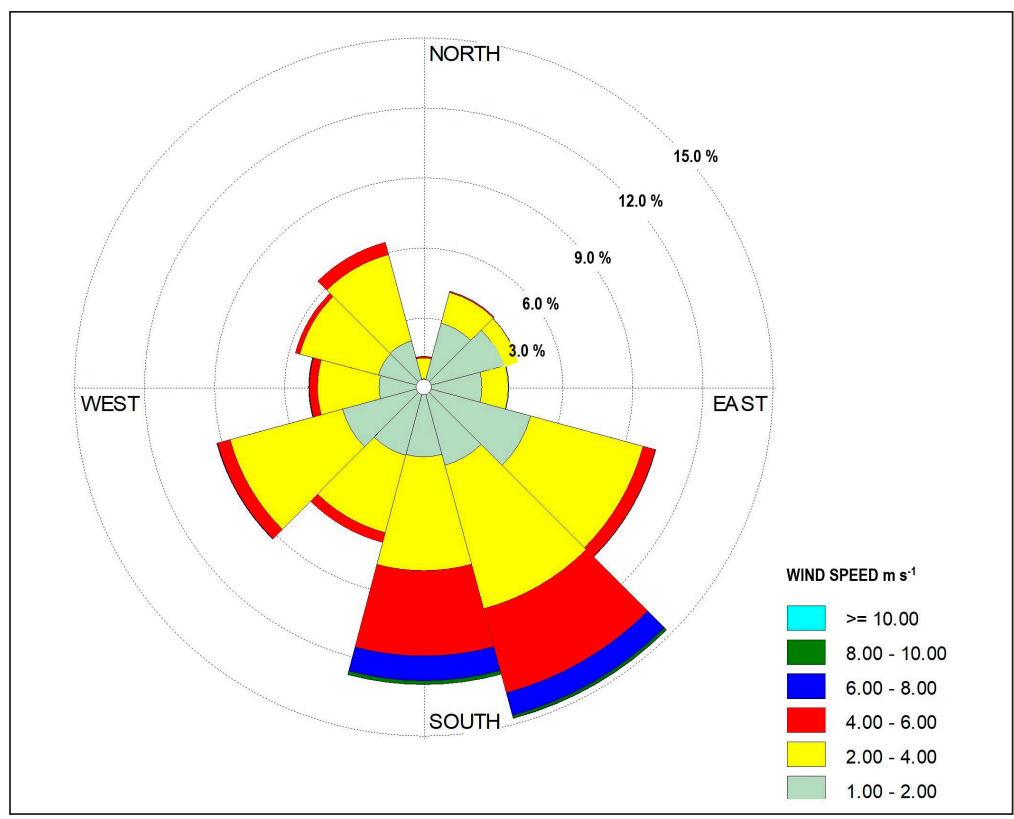

Fig. 1: 2012-2016 combined wind rose in Štítná during the period March 15 - October 31. 


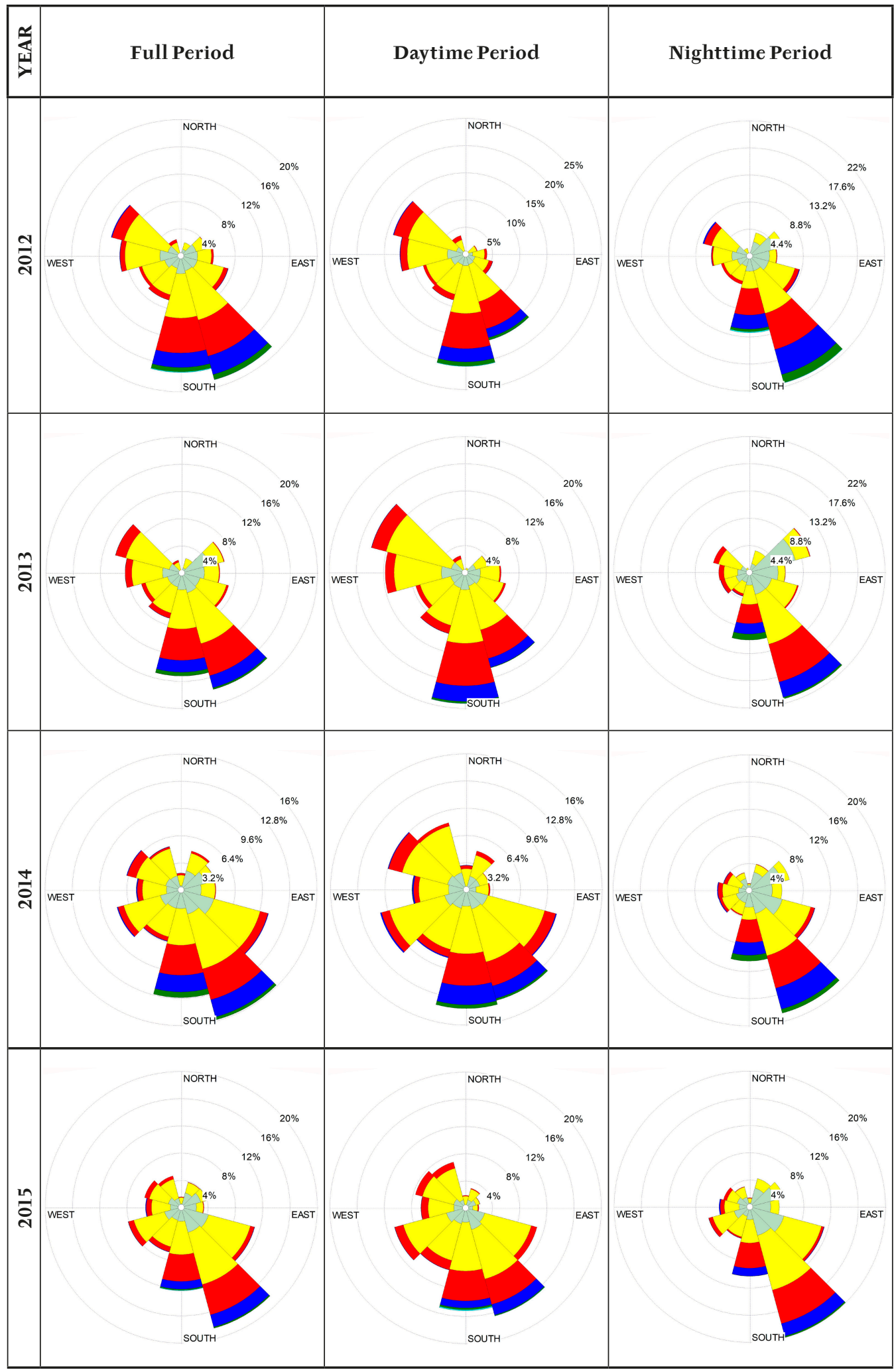




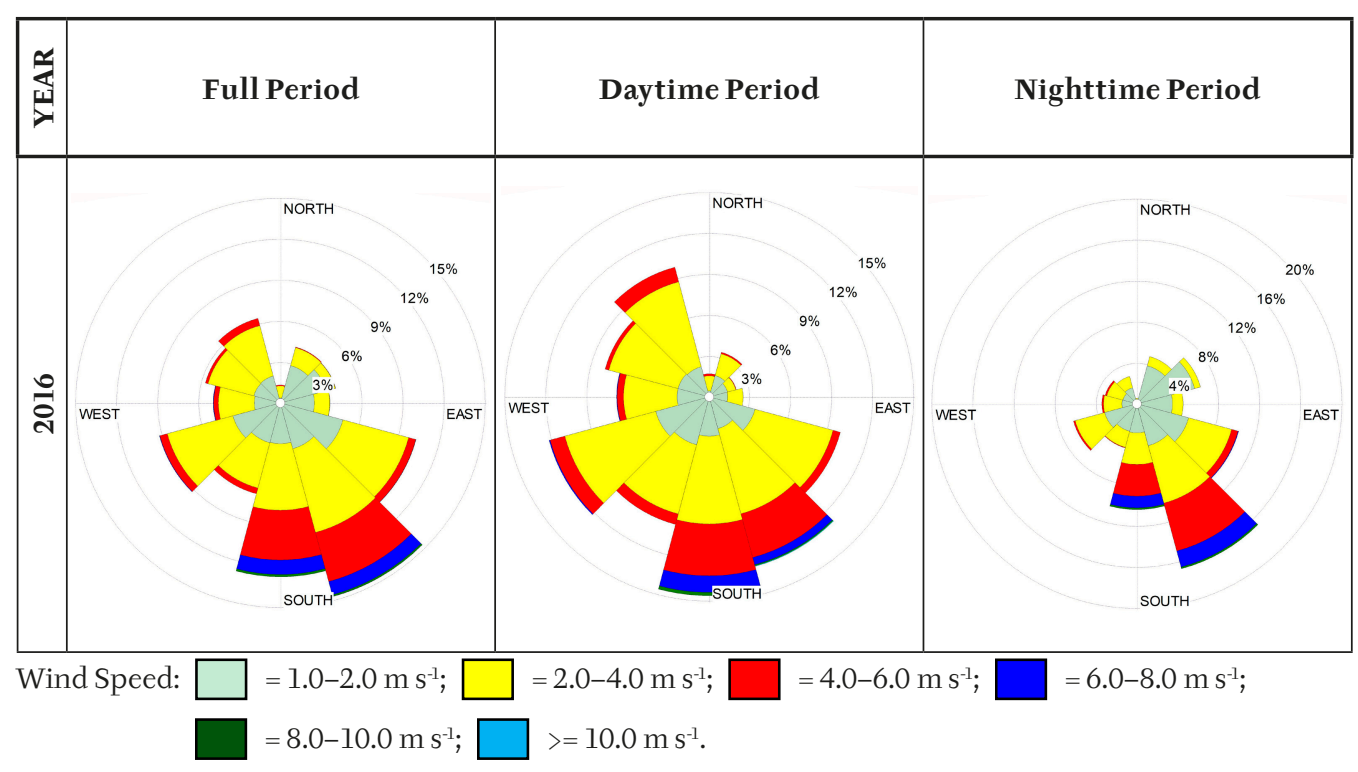

Fig. 2: Yearly growing-period wind roses from Štítná (March15 - October31).

\section{Discussion}

The eddy-covariance measurement of the carbon fluxes between forest and atmosphere requires to a well-known origin of the sources or destiny of the measured compound (Aubinet et al. 2012; Baldocchi 2003; Burba 2013). The wind analysis and its characteristics in a research eddy-covariance station as that one located in Štítná had vital information in order to realize the correct estimation and assignment of the carbon uptake or produced. In addition, the use of this technique has its own requirements and the exactly area of interest must be addressed (Baldocchi 2003). Using the meteorological data, we were able to produce and sketched the wind rose that had been measured from 2012-2016 in Štítná ecosystem station.

Consistently, yearly analysis (2012-2016) of the wind site conditions in Štítná indicated us that during the nighttime there is a marked difference and reduction from wind coming from South and then the predominant footprint area change from South to South-South-East (as is showed in the Fig. 2). Accordingly, to our results in the Tab. 2 the average wind speed varies from $2.34 \mathrm{~m} \mathrm{~s}^{-1}$ (2016) to $2.86 \mathrm{~m} \mathrm{~s}^{-1}$ (2012). Based on these results the variation in the wind speed during these years is maximum $0.55 \mathrm{~m} \mathrm{~s}^{-1}$.

The Štítná forest in which our ecosystem station is part has reached full forestry development the years and can be harvested in the next future. In the case of future harvest if it will be possible, some suggestions can be made in order that avoid clearcutting that will affect of the fetch and footprint of the EC. Specially, avoid areas in the direction South, South-South-East and SouthEast of the actual location of the tower. The previous is because the eddy-covariance technique is sensible to disturbance of fetch area and provoke errors in the interpretation but also, as is suggested (Baldocchi 2003) it can be used to quantify environmental perturbations.

Knowing the precisely contributions of wind directions can be helpful at the moment of taking managing decision for keep or moving the ecosystem station. Future research questions arise from the potential removal of trees of the Štítná station site as pointed out by Baldocchi (2003). But also footprint calculations should be routinely performed to evaluate the site wind contributions (Savage and McInnes 1996). 


\section{Conclusion}

We determined that three main wind directions contribute with nearly $40 \%$ of the wind from the direction South, South-South-East and SouthEast and from that, $82 \%$ of wind speed range among 1.0-6.0 $\mathrm{m} \mathrm{s}^{-1}$ between 2012-2016. Similar values were registered in the CHMI-SNVA of reference.

Knowing the precisely contributions of winds directions can be helpful at the moment of make managing decision of keeping or moving the station to have a proper fetch and footprint from the interested, since this technique and station intention is to evaluate the beech forest in the White Carpathian's zone. In the worse scenario if the footprint in the tower is affected by the removal of the trees, valuable information can be analyze in the future, to evaluate the affectations caused due to that removal and help to describe the way it is caused, which will improve the eddy-covariance technique.

\section{Acknowledgements}

University of Panama for provide the resources to allow the author (C.G.) the studies in the Czech Republic. This work was supported by the Ministry of Education, Youth and Sports of CR within the National Sustainability Program I (NPU I), grant number LO1415.

\section{References}

Aubinet, M., Vesala, T. Papale, D. (eds.) 2012: Eddy-covariance a practical guide to measurement and data analysis. Springer, London, UK, $438 \mathrm{p}$.

BALdocchi, D. 2003: Assessing the Eddy Covariance technique for evaluating carbon dioxide exchange rates of ecosystems: past, present and future. Global Change Biology, 9: 479-492.

Burba, G. 2013: Eddy Covariance Method for Scientific, Industrial, Agricultural, and Regulatory Applications: A Field Book on Measuring Ecosystem Gas Exchange and Areal Emission Rates. LI-COR Biosciences, Lincoln, NE, USA, 331 pp.

Czechglobe 2017: Meteorological Database of research sites (MeteoDBS-Štítná NAD Vlárí) of the Global Change Research Centre, AS, ČR, v.v.i. Brno, Czech Republic. Accessed on September 15, 2017.
European Environment Agency (EEA), 2007: European forest types, Categories and types for sustainable forest management reporting and policy. EEA technical report 9/2006. $2^{\text {nd }}$ edition.Copenhagen, Denmark. Accessed on September 11, 2014 in the following web site http://www.eea.europa.eu/publications/technical_report_2006_9

Marková, I., PavelKa, M., Janouš, D. 2017: Ročenka meteorologických mërení 2013. Yearbook of meteorological measurements in 2013. Brno: CzechGlobe, 168pp. ISBN 978-80-87902-19-6.

Metone 2017: 50. 5 Solid State Wind Sensor. Accessed November 3, 2017. http:// metone.com/meteorological-sensors-systems/ wind/50-5-solid-state-wind-sensor/

Ministry Of Agriculture Of The Czech Republic (MZe) 2013: Information on forest and forestry in the Czech Republic by 2012. Těšnov, Prague. 36 p. http://eagri.cz/ public/web/file/272639/ZZ_2012_ENG.pdf (Accessed on September $11^{\text {th }}$ of 2014).

Savage, M.J., Mcinnes, K.J. 1996: The "footprints" of eddy correlation sensible heat flux density, and other micrometeorological measurements. South African Journal of Science, 92(3): 137-142.

Weblakes, 2017: Software Wind Rose Plots for Meteorological Data (WRPLOT) view version 8. 0. 0. (Granted Access on October 01 of 2017).https://weblakes.com/. 